専門医症例報告

\title{
重度の咬耗歯の審美改善をフルジルコニアのクラウン用いて修復した 1 症例
}

\author{
小正 聡
}

\author{
A Case of a Full Zirconia Crown for Severely Attrited Teeth
}

Satoshi Komasa

\begin{abstract}
抄 録
症例の概要：患者は初診時 69 歳の女性。近医にて全顎的に著しい咬耗を指摘され，本科に来院，歯痛はないが， 咬耗歯と補経装置の審美的改善を長期にわたつて変色や破折がない材料による補綴処置を希望された。全顎に わたる咬耗，骨隆起，補経装置にマージンの不適合を認め，検査を行った結果，全顎的な咬耗症と診断した。 考察：全顎的な咬耗に対してオクルーザルスプリントを用いて顎機能の安定を確立し，審美性と強度を兼齐備 えたフルジルコニアのクラウンを利用することでその後の咬耗を防止することができた。

結論：咬耗に対し適正な補綴処置を施すことで, 咀嚼機能および審美障害を回復し, 患者の満足を得ることが できた。

キーワード

咬耗，オクルーザルスプリント，ジルコニア
\end{abstract}

\begin{abstract}
Patient: The case of a 69-year-old woman who visited our clinic with a chief complaint of poor esthetic appearance of the full mouth is reported. She exhibited no toothache, but requested esthetic improvement of dental attrition and inappropriate restoration, and specified the use of a material that does not discolor or fracture for an extended period. As a result of the examination, the patient was diagnosed with severely attrited dentition with torus mandibularis, and inappropriate restoration.

Discussion: Using occlusal splints for the severely attrited dentition, stability of jaw function was established. By using a full zirconia crown that was both esthetically pleasing and strong, subsequent attrition was prevented.

Conclusion: By applying proper prosthetic treatment in this case of severely attrited dentition, the patient's mastication ability and esthetic dissatisfaction were resolved.
\end{abstract}

Key words:

Attrition, Occlusal splint, Zirconia

\section{I. 緒言}

治療計画を左右する機能上のリスク因子として，ブラ キシズムや咬耗が挙げられる。それらをクラウンブリッ ジで修復しないといけない場合，補綴装置の破折が生じ やすく，患者との信頼関係が損なわれることは少なくな
今回，全顎にわたる重度の咬耗症と診断された患者に 対して，オクルーザルスプリントの装着, 歯周処置を含 めた包括的な治療を行い, 審美性と強度を兼叔備えた ルジルコニアのクラウンを用いて修復した結果, 良好な 経過が得られたので報告する。 is.

大阪歯科大学欠損歯列補綴咬合学講座

Department of Removable Prosthodontics and Occlusion, Osaka Dental University 受付 : 2017 年 10 月 13 日/受理 : 2018 年 6 月 25 日

Received on October 13, 2017/Accepted on June 25, 2018 


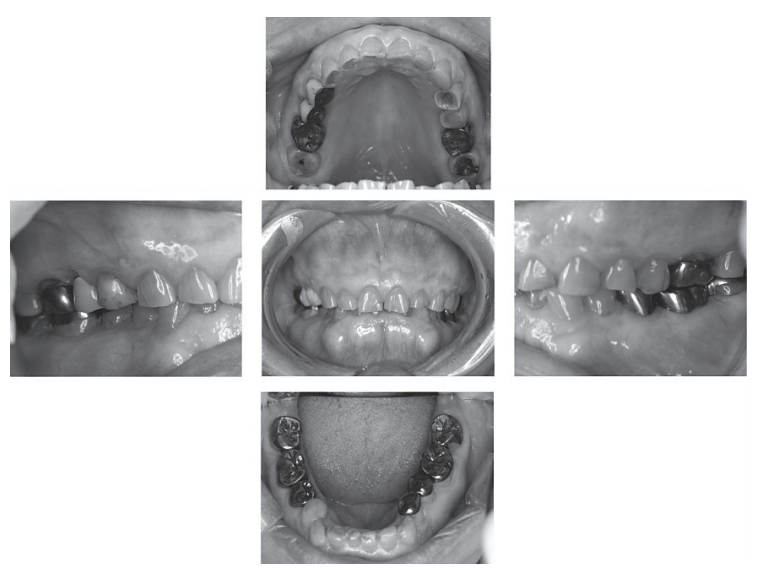

図 1 Intraoral views at the first visit 初診時の口腔内写真

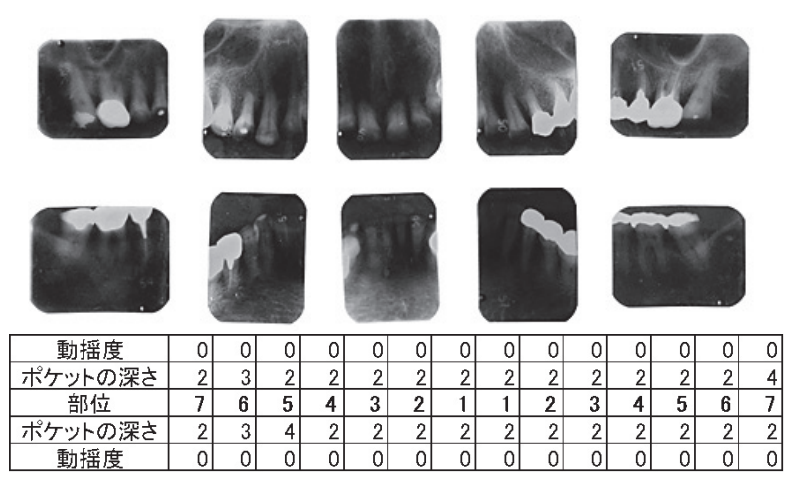

図 2 Dental radiographs and periodontal conditions at the first visit

初診時のエックス線写真および歯周基本検査

\section{II. 症例の概要}

患者 : 初診時 69 歳の女性.

初診日：平成 21 年 12 月 24 日。

主訴：咬耗症による審美障害。

既往歴：高血圧症，甲状腺機能低下症，人工関節（股 関節）

現病歴：近医にて全顎的に著しい咬耗を認め，専門医 での治療が必要であると判断され，平成 21 年 12 月大 阪歯科大学附属病院補綴咬合治療科に紹介され来院，歯 痛はないが，咬耗歯と不適切な補経装置の審美的修復を 長期にわたって変色や破折がない材料により補綴処置し てほしいという希望であった（図 1）。

現症：全顎にわたる咬耗，骨隆起，煩舌側の骨膨隆を 認め, 残存歯は電気歯髄診の結果，5，4456は失活歯で, 残りの歯は生活歯であった。6」，65，〈6 に全部金属冠， 45部分被覆冠，7」，7，4567 にインレーが装着さ れていた。エックス線写真検査 (図 2) と歯周基本検査(図 2 ）の結果を示す。患者にブラキシズムの自覚はないと のことだが，咬合時の違和感があるとのことであった．
表 1 Occlusal contact inspection by blue silicon ブルーシリコーンによる咬合接触の評価

\begin{tabular}{lcccccc}
\hline & \multicolumn{3}{c}{ 咬合接触面積 $\left(\mathrm{cm}^{2}\right)$} & \multicolumn{3}{c}{ 咬合接触点(数) } \\
\cline { 2 - 8 } & 左側 & 右側 & 計 & 左側 & 右側 & 計 \\
\hline 初診時 & 19.4 & 35.4 & 54.8 & 14 & 30 & 44 \\
平成23年1月 & 46.1 & 38.7 & 84.8 & 24 & 19 & 43 \\
平成23年3月 & 39.4 & 46.5 & 85.9 & 24 & 21 & 45 \\
平成28年5月 & 53.4 & 32.5 & 85.9 & 23 & 23 & 46 \\
& & & & & & \\
\hline
\end{tabular}

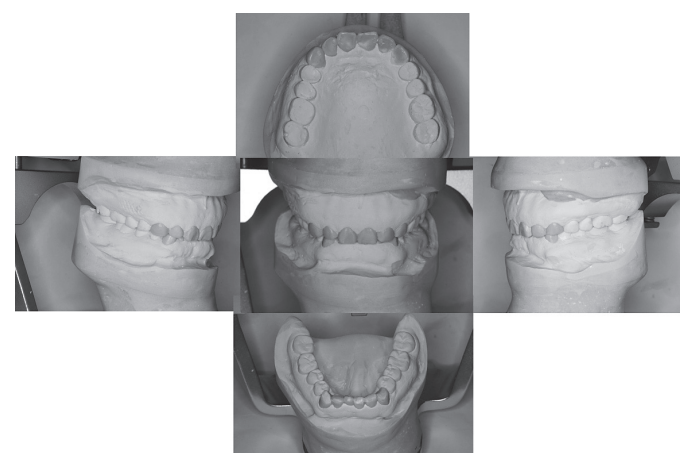

図 3 Diagnostic wax-up 診断用ワックスアップの写真

検査結果：歯槽硬線は明瞭で，歯根膜腔の拡大，歯 根の破折は認めなかった。歯周ポケットは $4 \mathrm{~mm}$ 以下, 動摇度 0 であった。ブルーシリコーンによる咬合検査 では，弱噛みと強噛みで咬合接触の位置は変わらず，接 触面積の増大がみられた。左右側それぞれの咬合接触面 積は異なっていた（表 1)。

診断：今回の症例では，全顎にわたる咬耗，骨隆起， 不良な補綴装置を認め，咬合検査，歯周組織検査などを 行った結果, 全顎的な咬耗症と診断した。

\section{III、治療内容と経過}

治療方針および計画：治療方針として，フェイスボウ トランスファー, チェックバイトを採得し, 半調節性咬 合器に装着した。診断用ワックスアップを製作し，前歯 部の形態を決めていくことにした。オクルーザルスプリ ントを装着し顎機能障害の診断を行うこと，歯周治療を 行うこととした。患者は審美改善および全顎的に積極的 に補綴処置を行うことを希望しており，長期に耐久性の ある歯冠修復物による補経を希望していることから，各 種補綴材料の利点, 欠点を説明し, ジルコニアの使用に 了解を得た。ブロックごとにプロビジョナルレストレー ションを装着してから，フルジルコニアのクラウンを装 着する治療方針とした。

処置内容: 平成 22 年 2 月, 顎機能障害の診断を目的 にオクルーザルスプリントを上顎に装着した。歯科医療 領域 3 疾患の診療ガイドライン 2002 II。顎機能障害 


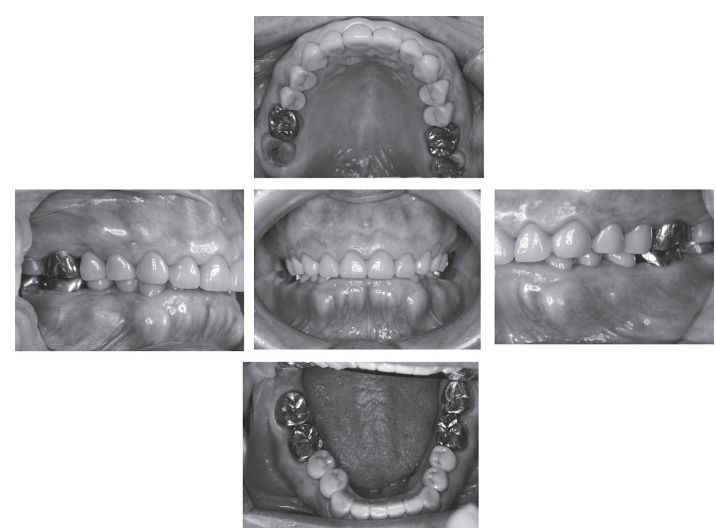

図 4 Intraoral views after prosthetic treatment 上下顎補綴装置装着時の口腔内写真

の診療ガイドラインに従い，2-3 カ月の使用を基本とし て, 来院毎にブラキシズムによる圧痕や摩耗の程度を検 査しながら咬合状態をチェックするとともに，必要に応 じてオクルーザルスプリントの咬合調整を行った。 ま た, 大阪歯科大学歯周治療科にて全顎的歯周治療を行 い，口腔内の清掃状態を管理した３力月の経過観察の 間，ブルーシリコーンによる咬合検査でも弱い噛みしめ （50 N 以下）および強い噛みしめ（50 N 以上）で咬合 接触部位に変化はなく，咬合接触面積が増加するという 検査結果，また患者自身にも日常生活時に機能障害を認 めないことから，顎位を変化させずに咬耗した部分の歯 の補綴処置を行うこととした。上顎前歯部に関しては審 美的修復を目指し, 大阪歯科大学保存修復科にて事前に ホワイトニングを行ったものの効果は得られず，補綴処 置を行うことで同意をいただいた。

フェイスボウトランスファー, チェックバイトを採得 し, 半調節性咬合器に装着し, 頭蓋に対する上顎歯列の 三次元的位置関係を記録した。咬合高径を変化させずに 診断用ワックスアップを製作し，前歯部の形態を決定す ることとした（図 3)。なお，大白歯部は形成量および 経済的な理由により,審美的修復は行わないこととした。 歯冠補綴に関しては, 長期にわたつて変色や破折がない 材料を希望されたことから, 審美性と強度を兼社備えた フルジルコニアによるクラウンの利点欠点を説明し， フ ルジルコニアのクラウンによる補綴処置を行うことで同 意を得た。当時，フルジルコニアのクラウンに関する長 期観察を行った臨床論文は少なく, リコール時に咬合状 態を注意深く観察する必要があることを十分に説明した 上で治療を開始した。

オクルーザルスプリント装着 3 カ月の経過観察後, 咬頭嵌合位が安定していることを確認し, 不良な補綴装 置であった 6 の全部鋳造冠および 67 のインレーを除 去し, 咬頭嵌合位が変わらないように注意しながら, 平 成 22 年 8 月全部金属冠を装着した。また, 全部金属冠 の装着に合わせてスプリントを修理した。

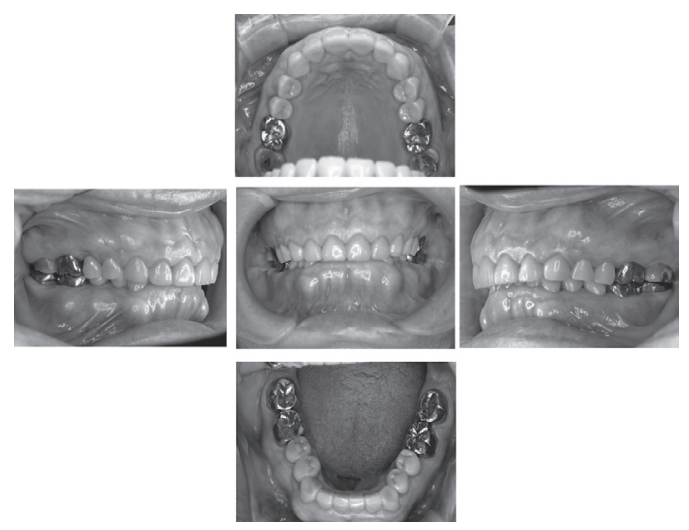

図 5 Intraoral views at five years after treatment 5 年経過時の口腔内写真

平成 22 年 10 月から平成 23 年 1 月にかけて, 45 , $45 ， \overline{45}, 4$ 45」のブロック毎に浸潤麻酔後, 支台歯形成 を行い, 診断用ワックスアップをパテで採得し, 即時重 合レジン（ユニファストIII, ジーシー, 東京, 日本）に よりプロビショナルレストレーションを装着し, 精密印 象, 咬合採得を行い, フルジルコニアのクラウンを装着 した。

平成 23 年 1 月, $321 \mid 123$ に浸潤麻酔後, 支台歯形成 を行い，診断用ワックスアップをパテで採得し，プロビ ショナルレストレーションを装着した， $1 \mid 1$ は翼状捻転 していたため, 唇側の豊隆を付与した。 また, 患者の希 望により，歯冠長を若干伸ばした。平成 23 年 2 月フル ジルコニアのクラウンを装着した。 なお，咬耗により高 径が低かったことから上顎前歯部は 2 本ずつの連結冠 で作製した。

平成 23 年 2 月, $\overline{321 \mid 123}$ の支台歯形成を行う前に, 形成量の確認を再度行った後, 咬耗により下顎前歯部 の高径が低かったことから技工士とも相談の結果，3， $\overline{21}$, 1 ,, 23 の連結形態のフルジルコニアのクラウン を作製することで同意を得た。浸潤麻醉後, 支台歯形成 を行い，診断用ワックスアップをパテで採得し，プロビ ショナルレストレーションを装着し, 2 回に渡り, 歯肉 整形を行った。平成 23 年 3 月 2 日フルジルコニアのク ラウンを装着した（図 4)。ブルーシリコーンによる咬 合検査は適正であった。 また, 有歯顎に与える咬合様式 としては犬歯誘導かグループファンクションが一般的で あるが, 臼歯部への負担軽減も検討し, 与える側方運動 時の咬合接触は犬歯誘導とした。治療期間中はオクルー ザルスプリントを修理して使用していたが，補綴処置終 了後に再製作した。

術後の経過: 平成 23 年 3 月以降, 最終補綴装置を装 着後, ブルーシリコーンによる咬合検査と歯周治療を定 期的に行い, 必要に応じてオクルーザルスプリントの咬 合調整を行っている。平成 28 年 5 月， 5 年経過をみる が，咬合違和感や痛みもなく，良好な結果を得ている 
(図 5).

術後の機能評価: 平成 28 年 5 月時点において，歯周 基本検査から，歯周ポケットは $4 \mathrm{~mm}$ 以下，動摇度は 0 であった。エックス線写真検査において，歯槽硬線は明 瞭で，歯根膜腔の拡大，歯根の破折は認めなかった。ブ ルーシリコーンによる咬合検査では, クラウン装着後, 5 年経過時まで咬合接触面積に大きな変化は認めなかっ た。

\section{IV. 考 察}

歯科治療において，なるべく歯を削らない，抜かない という治療概念の普及と共に，う蝕や歯周疾患に続く疾 患として，咬耗が注目されている，症状を把握しなけれ ば今後発現する可能性のある症状やその対応を予測する ことはできず，治療介入にも慎重な治療計画の策定が必 要とされる.

本症例のように，年齢の平均よりも高度に摩耗した患 者では，その発生原因を無視して治療に介入すると，患 者に対する負担は著しいものとなる。主要な咬耗の原因 としては, ブラキシズム, 強い咬合力, 安静空隙の喪失, 悪習癔等が挙げられ，咬耗の結果，咬合高径の低下，咬 頭嵌合位の不明瞭，顎位に前方への変位，顎関節症の悪 化等を誘起する可能性が起こる。本症例では咬耗の原因 である悪習㾕は患者に対する問診の結果，除外された。 患者が高年齢であることおよび骨隆起の存在からブラキ シズムが疑われ，オクルーザルスプリントによる 3 カ 月の診断を行ったが，顎機能に異常は認めなかった。大 阪歯科大学附属病院補経咬合治療科では咬頭嵌合位なら びに顎機能の精査としてバイトアイを使用したブルーシ リコーンによる咬合検査を行っている，田中 ${ }^{1)} ら の$ 報告 では，本法は咬頭嵌合位の再現に最も優孔ているとされ ており，咬合検査の手法として，強い噛みしめと弱い喽 みしめの測定を行い，咬合接触面積の左右側の均衡を確 認するとともに，噛みしめ強度の向上に合わせて，咬合 接触部位が変わらず，咬合接触面積の夕増加するかどう かを顎機能の異常評価として推奨している．本症例では オクルーザルスプリントの装着後も顎機能の異常は認め なかった。咬耗に誘起される咬合高径の低下に対する処

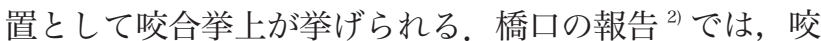
耗に咬合高径の低下を認めた症例に対し，咬合挙上を適 用することで，良好な治療経過を得たとしている。しか し，樋口の報告では ${ }^{3)}$ ，過度の咬合挙上が頭痛，ブラキ シズム，咀嚼筋の筋痛，顎機能時の顎関節周囲の痛みを 生じるとしており，咬合挙上には十分な治療期間と患者 の理解が必要である。本症例では患者に行った各種検査 結果を患者に十分に説明し，今後の治療計画について相 談したところ，咬合挙上を患者が望まず，現在の咬合高 径を維持したままの補綴治療を希望されたため，本法を 選択することとなった。明確なブラキシズムの症状は認
めなかったものの, 患者の年齢から考察してもアクティ ブなブラキサーである可能性があり歯周組織への影響も 不安視される。その理由によりブラキシズムの診査後も オクルーザルスプリントは使用し, 補綴装置の装着後も オクルーザルスプリントを修理し，現在も使用を継続し ている.

咬耗を生じている歯に対し使用される補綴装置は限ら れる。強い咬合力に耐えうる材料としては金銀パラジウ 厶合金や金合金をはじめとする金属材料が主であり，硬 質レジンや陶材による前装は破折等の恐れがあり，審美 性の点で不利益が多い. 本症例においては咬頭嵌合位を 長期に安定させること，審美面の回復を図ること，破折 の心配の無い材料を選択する場合，ジルコニアが補綴装 置に使用する材料として挙げられる。ジルコニアは優れ た強度と勒性を持つバイオマテリアルであり, 現在では 審美的修復への臨床応用が多くなされている．本症例の 開始時期には，ジルコニアの普及は十分とはいえず，臨 床症例も限られていた。また，オールセラミック修復は 支台歯の形成量も多く，歯髄の負担も考えられるととも に，レイヤリング修復であれば陶材の破折の可能性も考 えられる。

そこで，患者の破折することなく長期に保存のできる 補綴装置の希望を元に，ジルコニアの材料特性を十分に 説明し, 利点欠点を十分に理解していただいたうえで, ステイン法によるジルコニア修復を行った。臨床症例が 少ないことも鑑み，5年間にわたる治療経過を観察した ものの, 咬合接触に変化は無く, 良好な経過を示してい る。前装の使用無く, ジルコニアによる咬合接触の回復 を行うことは有用であると考える。

\section{V. 結 論}

重度の咬耗に対してオクルーザルスプリントを用いて 顎機能の安定を確立し，審美性と強度を兼亦備えたフル ジルコニアクラウンを利用することでその後の咬耗を防 止することができた。その結果，快適な咀嚼を行うこと ができ，患者の満足を得ることができたと思われる。

\section{文献}

1) 田中昌博，咬頭嵌合位での咬合接触に括目せよ。日補経 会誌 $2014 ; 6: 351-340$.

2）橋口亜希子. 咬耗症に対して補綴処置を行った 1 症例。 日補綴会誌 $2011 ； 3 ： 405-408$.

3）樋口景介，千葉雅俊，野上晋之介，高橋 哲。咬合挙上後 に顎関節に激痛と急速な骨変形を生じた変形性㖽関節症 の 1 例。日顎誌 $2016 ； 28 ： 151-157$.

著者連絡先 : 小正 聡

干 540-0008 大阪市中央区大手前 1-5-17

Tel: 06-6910-1517

Fax: 06-6910-1044

E-mail: komasa-s@cc.osaka-dent.ac.jp 